\title{
AN OUTLINE OF THE ARCHAEOLOGY \\ OF PEARY LAND
}

\author{
Eigil Knuth*
}

$\mathbf{P}$

EARY LAND marks the northernmost as well as the easternmost extent of the former Eskimo territory. Geographically the name covers only the most northerly peninsula of Greenland, which to the south is separated from the neighbouring territories of northeast Greenland by Independence Fjord, some 150 miles long and up to 20 miles wide. Archaeologically, however, the south coast and ramifications of Independence Fjord should be included in the Peary Land region, which thus extends from latitude $81^{\circ} \mathrm{N}$. in the south to $83^{\circ} 40 \mathrm{~N}$. in the north. The peninsula, which is some 16,700 square miles in area, is the largest ice-free region in Greenland, and its northern part, the most northerly of all known land.

Peary Land is almost 180 degrees east of the easternmost Eskimo territory in Bering Strait. However, Point Barrow, the northernmost point on the Alaskan mainland, is as much as 750 miles south of Peary Land, that is about half-way between the extreme south and north points of Greenland. Thus, climatic conditions for the inhabitants in ancient times, as well as opportunities for the archaeologist looking for traces of them, are very different from those of the archaeologically-rich districts of Alaska, where Larsen and Rainey (1948) were able to find ruins of a whole village site at Ipiutak.

Eskimo settlement in Peary Land has been on a modest scale, and the yield of our archaeological work, under the difficult conditions of snowcovered areas often at 40 degrees below zero, was also modest. Only a few hundred objects were brought home against tens of thousands from the Alaskan excavations. However, certain facts justify a description of the Peary Land observations. Because of the scarcity of settlements in Peary Land some culture evidence has been preserved with undisturbed, clear lines which distinctly divides the two complexes of modern Eskimo archaeology, paleo-Eskimo and neo-Eskimo. Our finds in the paleo-Eskimo complex are of particular interest as they correspond to the recent archaeological discoveries in Alaska.

\section{The Arctic Whale Hunting Culture}

Peary Land has been a transit region for Eskimo migrations from Arctic North America to northern East Greenland, ${ }^{1}$ and there is evidence that some at least of the migrations may have passed from the northern part of Ellesmere Island via Robeson Channel to the north coast of Greenland, thus by-passing the Thule district. The neo-Eskimo were, as might be expected, the latest arrivals, and the most important evidence of their stay in Peary Land was found at Herlufsholm Strand, the flat southeasterly point of the peninsula just north

*Leader, Danish Pearyland Expedition, 1947-50.

1The use of capital letters for East and West Greenland indicates the political, not the geographical region. $E d$. 


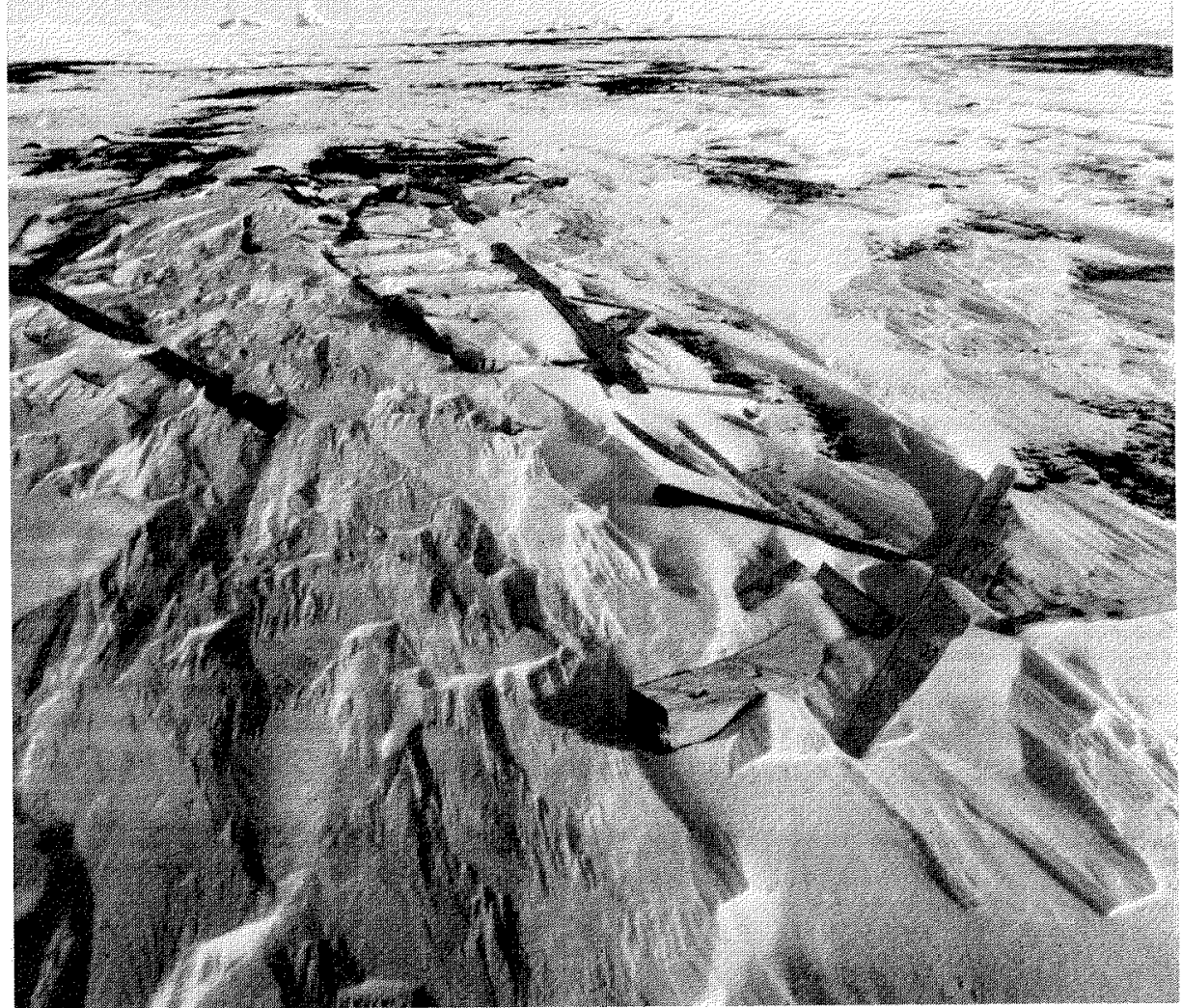

Fig. 1. Umiak frame at Herlufsholm Strand, shortly after discovery on 11 May 1949.

of the mouth of Independence Fjord. Here, on an almost snowfree gravel terrace facing the pack ice of the Arctic Ocean, we found the frame of an Eskimo whaling boat or umiak, which was over 35 feet long (Figs. 1 and 5), and about one hundred metres in front of it, under deep snow, there was a number of camping grounds full of abandoned utensils. For the present the objects may be described as of types characteristic of the Thule Culture: whaling harpoon heads, ground slate blades, sled-shoeing, trace buckles, and baleen implements (Fig. 2). The animal bones collected indicate hunting of the following animals: Greenland whale (Balaena mysticetus), narwhal (Monodon monoceros), bearded seal (Erignathus barbatus), ringed seal (Phoca bispida), muskox (Ovibos moschatus), reindeer (Rangifer tarandus), and arctic fox (Alopex lagopus).

The most remarkable find in many respects was the umiak frame. A photograph of it in situ was published in Arctic (Vol. 3(1950) p. 13) in a preliminary account of the first wintering of the Danish Pearyland Expedition, 1948-9, written while the expedition was still in the field. During several other sled journeys to the umiak the following year, 1949-50, all wooden 


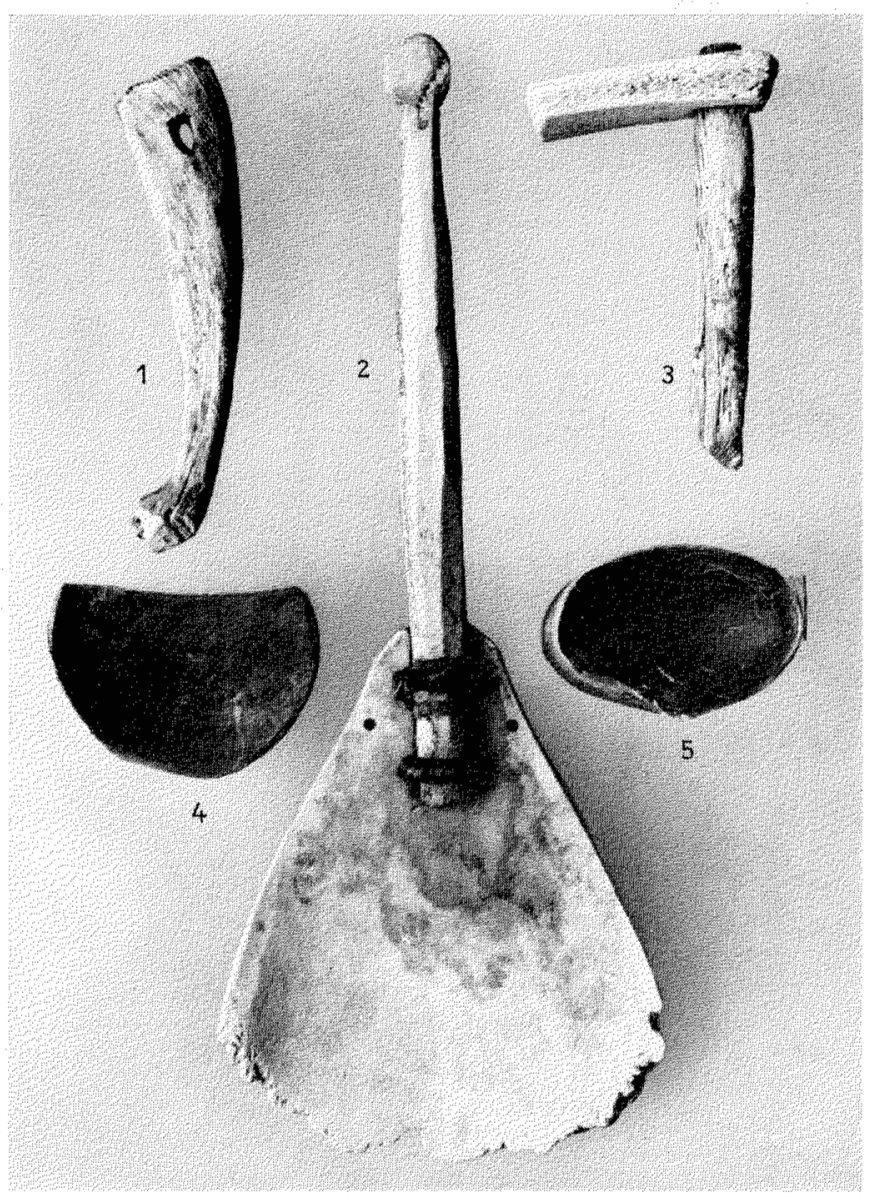

Fig. 2. Thule Culture utensils found near the umiak: (1) adze shaft; (2) whale bone spade; (3) blubber pounder; (4) meat tray; (5) box with baleen side and wooden bottom. Reduction ca. 1:6.

Fig. 3. Umiak paddle found on camping ground 100 metres in front of the boat. Reduction ca. $1: 6$.

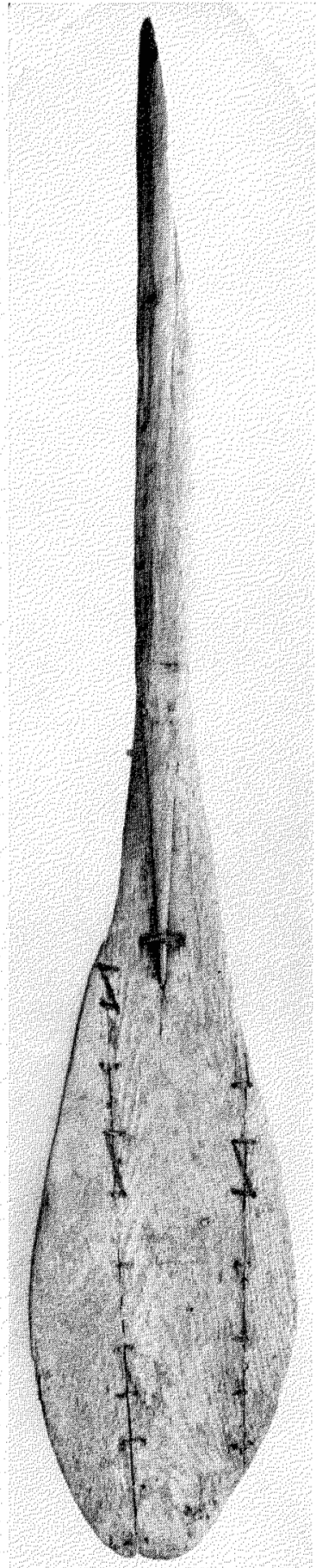




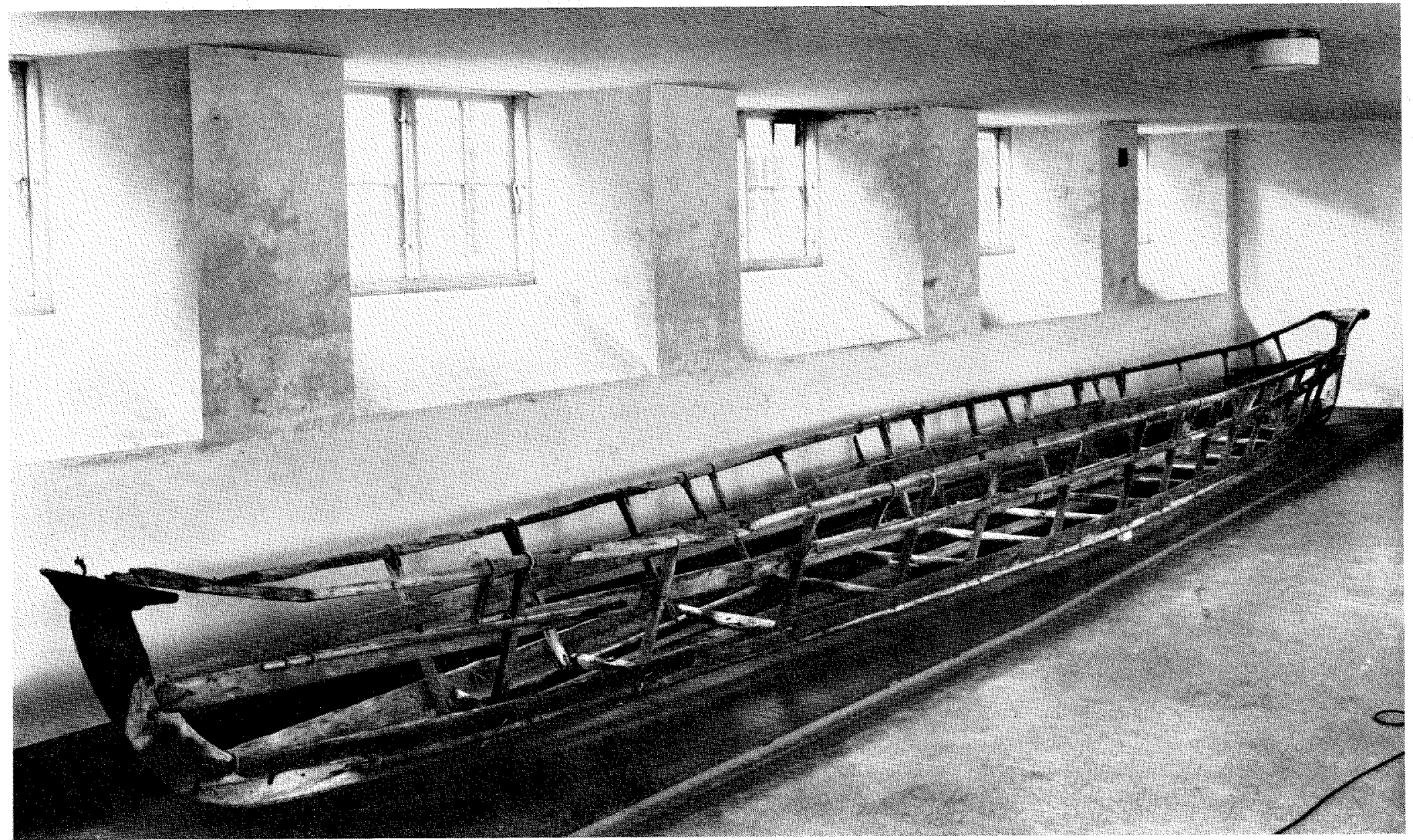

Fig. 4. The umiak rebuilt in the basement of the National Museum of Denmark, Copenhagen, June 1951. 

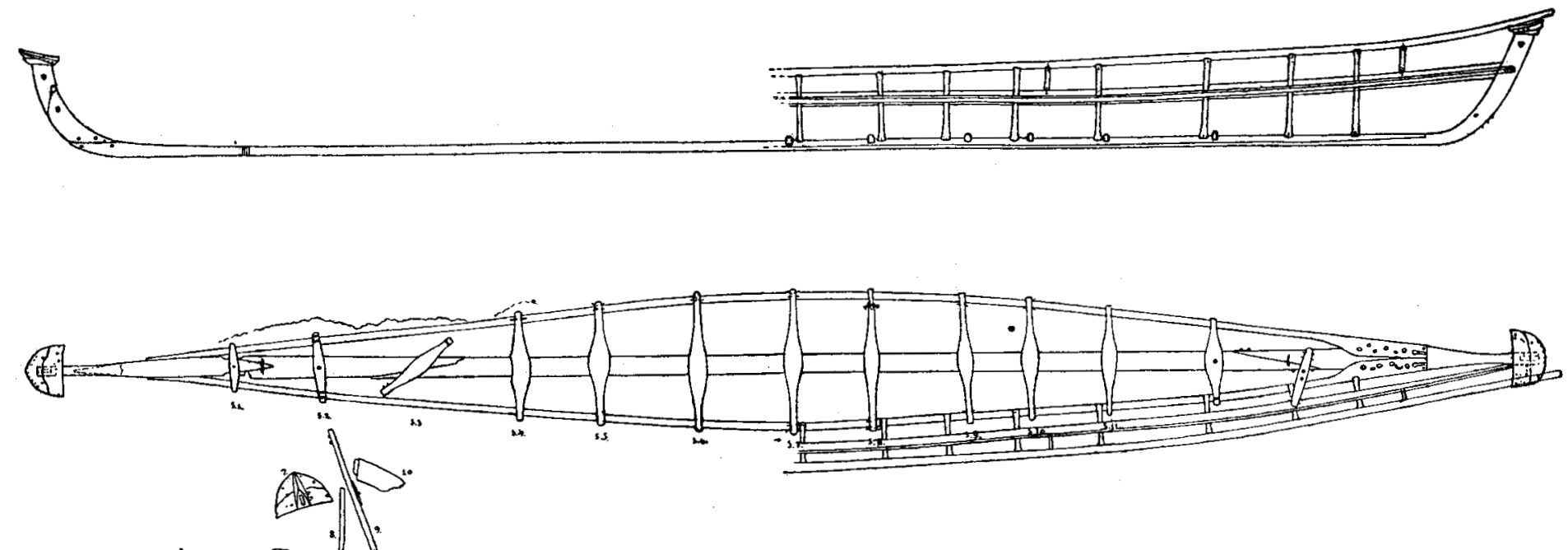

$$
\therefore \quad \therefore
$$

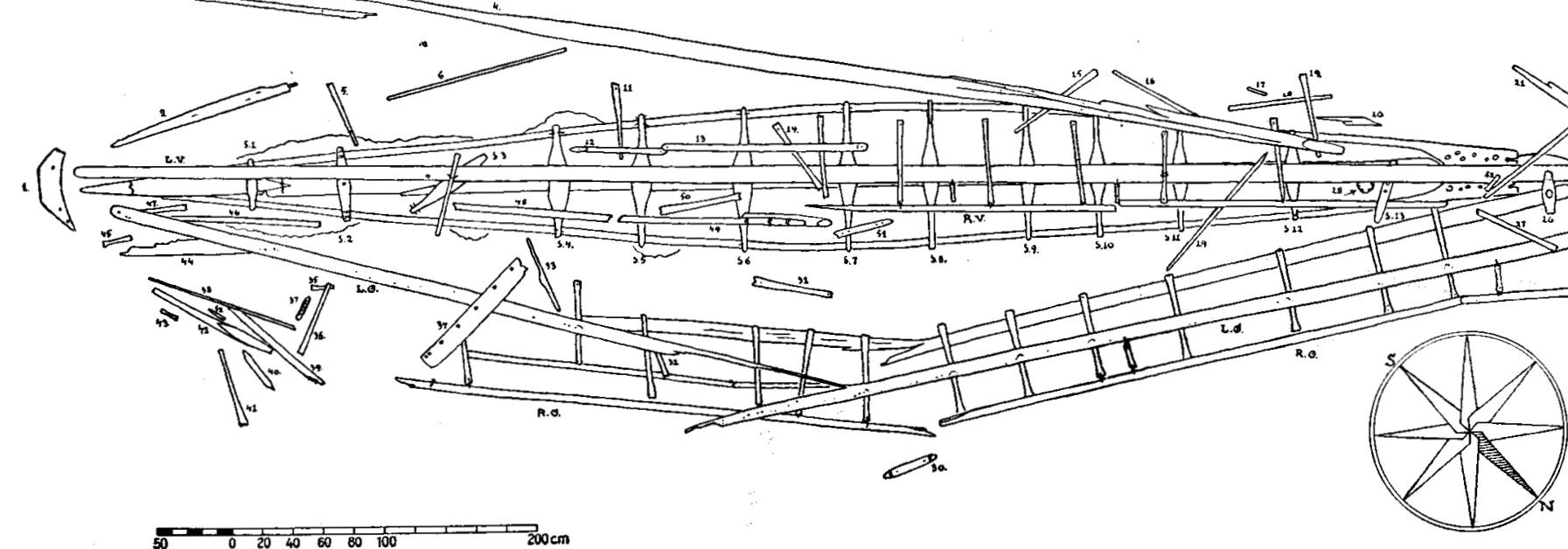

Fig. 5. Above: reconstruction of umiak. Below: uniak as measured in situ. 


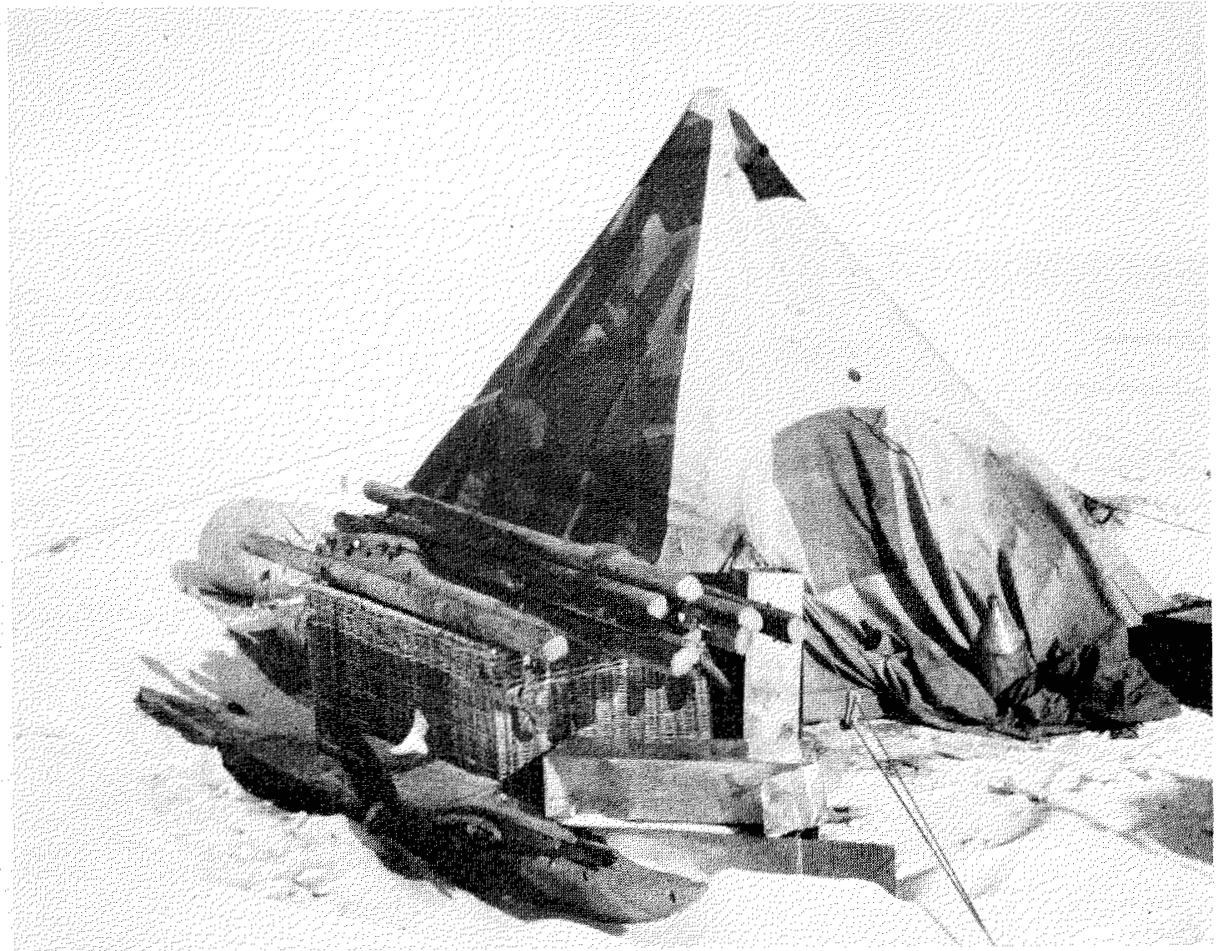

Fig. 6. The last parts of the umiak sawn in pieces, beside the expedition tent at Herlufsholm Strand, May 1950.

parts of the boat were removed to the wintering station at Jørgen Brønlunds Fjord, a small northern branch of Independence Fjord, 125 miles to the west. In the summer of 1950 Catalina aircraft carried the umiak 600 miles farther south to Zackenberg, from where it was taken to Denmark in the hold of the expedition ship. This umiak, which has been rebuilt and is now in the National Museum in Copenhagen, where it is the largest of all the Eskimo boats, probably made a journey no white man has yet completed-the voyage round the north coast of Greenland.

That this is so, can hardly be doubted. At the camping grounds near the umiak no elements from the characteristic Mixed Culture of northeast Greenland (Larsen, 1934) were found which might reveal a connection with the Eskimo from the parts of East Greenland which lie south of Peary Land. In its isolation on the barren coast the find suggested that the whalers did not stay long in the region, moreover, the boat showed signs of repairs and alterations proving that it could not have been built on the spot. These facts can only be brought into agreement if we assume that the immigration took place to the north of Greenland from the west. The boat itself, with its heavy keel plank, $7 \times 13 \mathrm{~cm}$ in cross section and of greatest width in the horizontal plane, and 13 cross pieces with broad, flat, convex-edged centre parts lying on the plank, confirms this assumption. The keel and the cross pieces in all 


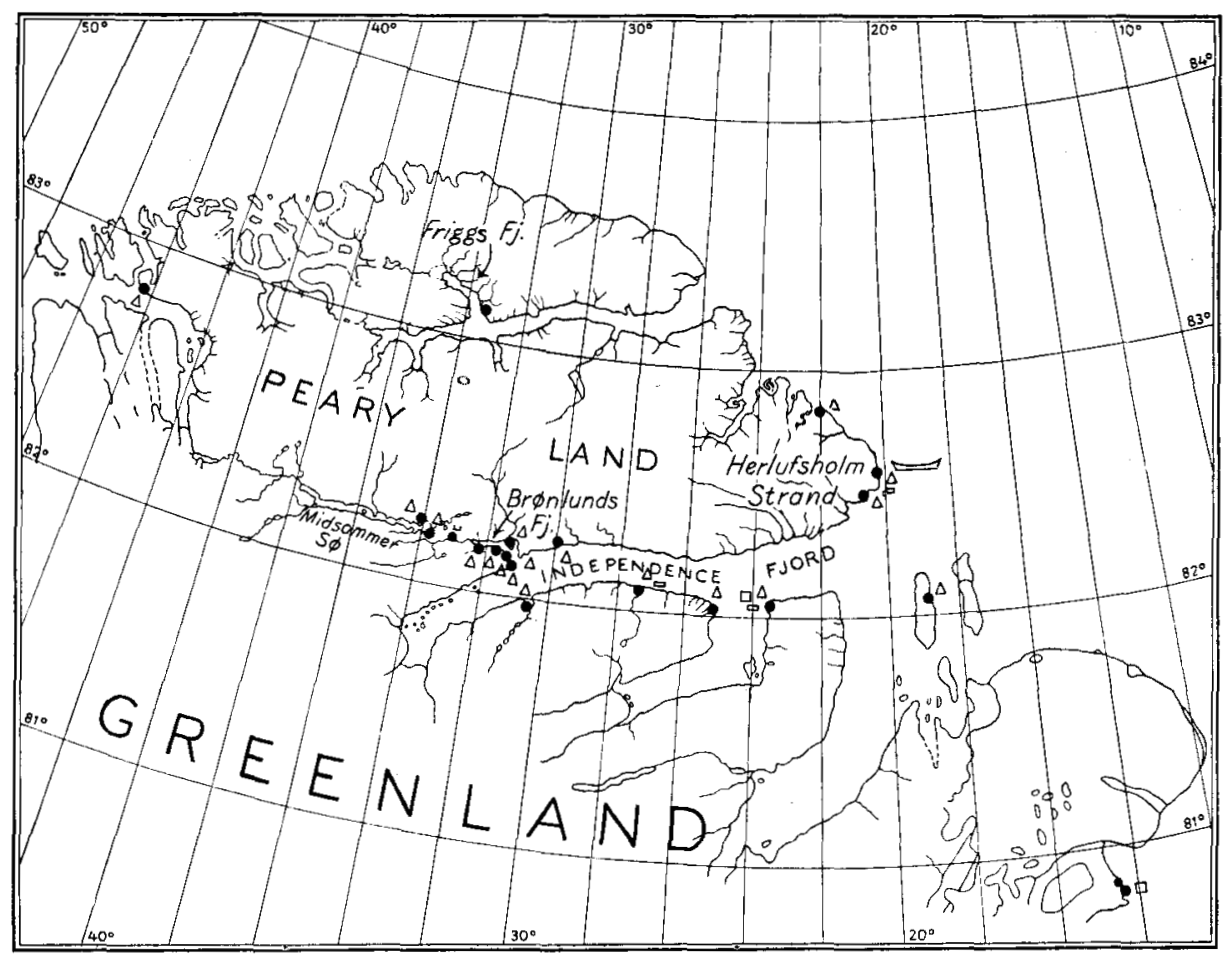

Fig. 7. Eskimo sites found by the Danish Pearyland Expedition, 1947-50. The boat marks the site where the umiak was discovered.

"women's boats", as we know them from Greenland, rest on the edge and to find a parallel it is necessary to go to Alaska. The publications of Collins (1937) and of Geist and Rainey (1936) contain pictures of similar cross pieces from umiak frames found on St. Lawrence Island, and Collins (1937, pp. 158-9) describes an end block from the prow or stern apparently identical with the end blocks from the Peary Land vessel. ${ }^{1}$

The wooden pieces of the umiak were held together with lashings of baleen and big spikes of walrus ivory with barbed points, but a small number of iron nails was also found in the boat. Spruce or larch driftwood was used for the construction, with the exception of a small piece from the port gunwale, which proved to be oak. Somewhere on the journey the Eskimo party must have met with white men or come across the wreck of a white man's ship from the waters west of Greenland, and this cannot have occurred more than 300 years ago. The good state of preservation of boat utensils tells of a much later date for the stay in Peary Land.

The immigration to Peary Land which appears to be represented by the umiak from Herlufsholm Strand seems in the first place to be the eastward spreading from Alaska of the Arctic Whale Hunting Culture. It is known

${ }^{1}$ The writer would welcome information on umiaks or parts of umiaks corresponding to the Peary Land find. 
that it populated the Thule district and Inglefield Land in North Greenland by several advances. It must be assumed that remains of pure Thule Culture must have been preserved somewhere in northern Ellesmere Island or on the islands to the west. The well-preserved sleds found by Greely (1888) at Lake Hazen, Distant Cape, and Pim Island in 1882-4 support this theory. From this reservoir of the Whale Hunting Culture the comparatively recent neo-Eskimo migration to Peary Land must have taken place $2-300$ years ago.

\section{The Dorset Culture}

Our archaeological investigations in the Peary Land area have so far discovered 31 sites with 146 dwelling remains in all, 18 smaller stone rings, 36 fire places, 41 meat caches, and 18 fox traps. Some were situated on the south coast of Independence Fjord, but the great majority were in Peary Land itself, where 25 sites including 121 dwelling remains, 4 smaller stone rings, 23 fire places, and 25 meat caches have been found. They all lie farther north than other ancient settlements hitherto described-the northernmost sites in Friggs Fjord, $83^{\circ} 07 \mathrm{~N}$. and $83^{\circ} 12 \mathrm{~N}$., being only 470 miles from the North Pole.

The walls of only one of the dwelling remains were sufficiently high for it to be called a "winter house" as we know it from the rest of the Eskimo world. The other dwellings were mostly "tent rings", but in many cases tent rings of a special type which will be discussed later. This type was particularly common in Jørgen Brønlunds Fjord where "Brønlundhus", the headquarters of the expedition, was situated. Here, far from the sea, traces of earlier dwellings were more numerous and closer together than anywhere else in the district, namely 15 sites with 84 dwelling remains, 3 smaller stone rings, 12 fire places, and 21 meat caches (Fig. 8).

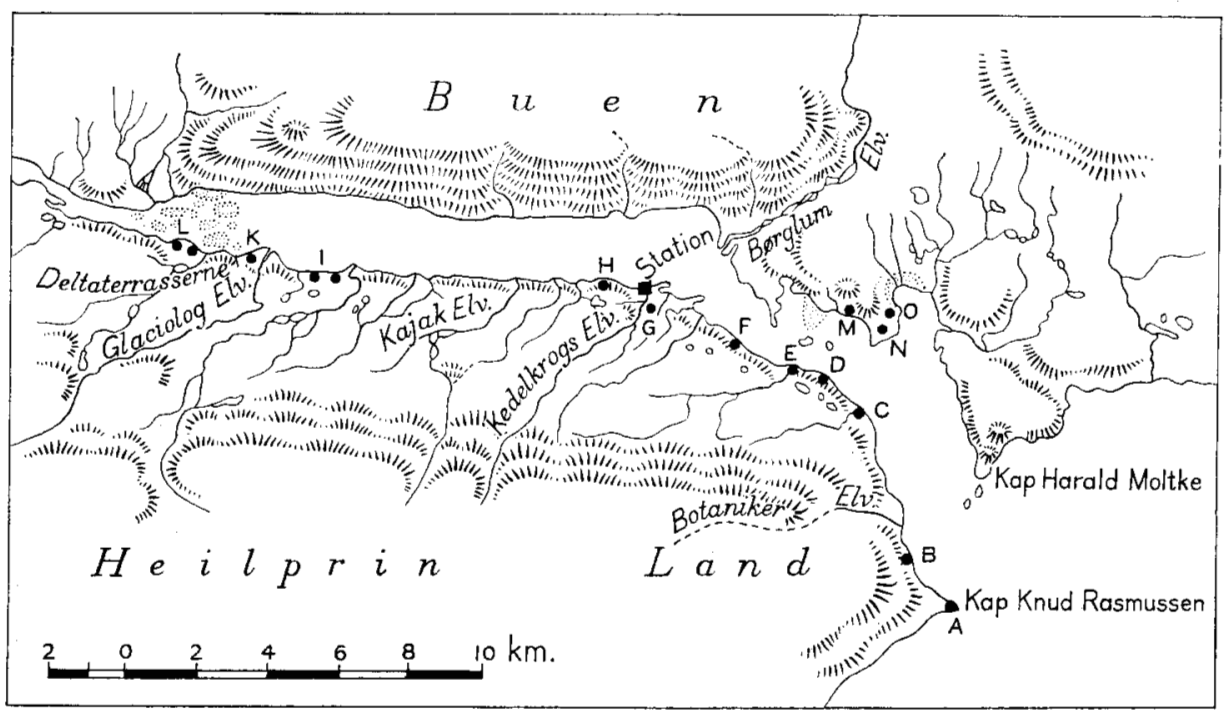

Fig. 8. Eskimo camping sites in Jørgen Brønlunds Fjord. 


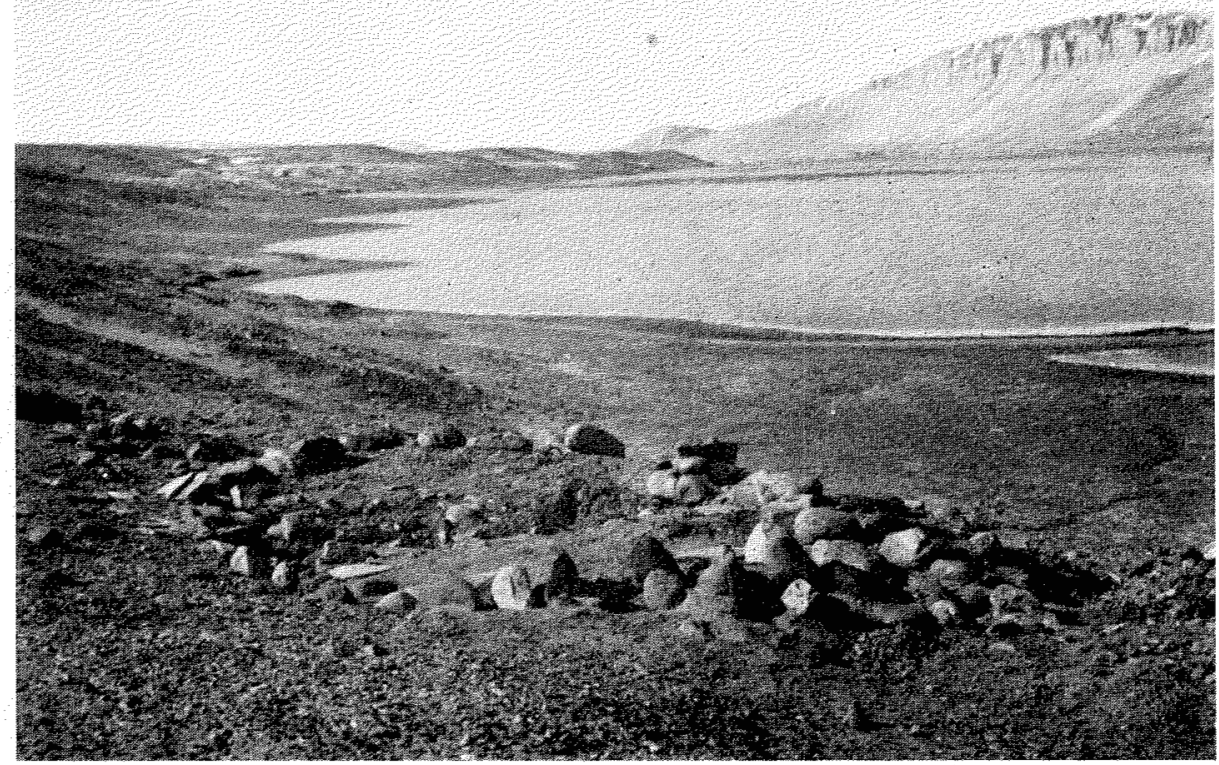

Fig. 9. Elliptical tent ring No. 5 with mid-passage at Deltaterrasserne, site K in Jørgen Brønlunds Fjord.

Professional Eskimo archaeologists have, in the past, concentrated their investigations on house ruins and paid less attention to the tenting places. Finds from tent rings were rare exceptions and never used as a guide. But Peary Land forced its tent rings on the archaeologist and taught him not to scorn them. It was very fortunate that the tent rings were chiefly distributed along the shores of Bronlunds Fjord, where members of the expedition were confined all summer after the spring sled journeys were over. No other circumstance would have driven an archaeologist to continue his scratchings and rummagings in sterile-looking gravel exactly like the gravel outside the stone circles, when one day passed after another without bringing forth the least bit of bone, wood, or artifact.

But perseverance had its reward, now here, now there, in finds of a tiny flint flake with traces of fine retouching along the edge. In the course of two years these sparse, small finds amounted to quite a collection telling its own story: tiny blades of flint, knife blades, scrapers, one roughly manufactured adze blade, and small flint lamellar flakes or "microliths". The blades in some cases were retouched along the edge to form two or three notches at the back, a measure giving better support to the lashing (Fig. 10, Nos. 16, 20, $21,22)$. The convex-edged scraper was comparatively well represented in finely executed, varied forms. At one of the tenting grounds a prepared flint core (Fig. 10, No. 13) was found from which microliths had been struck, the first find of its kind in East Greenland. Examples of the bone tool, or 


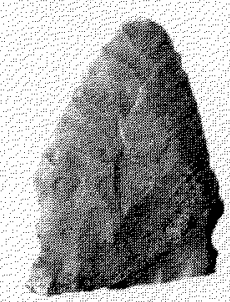

1
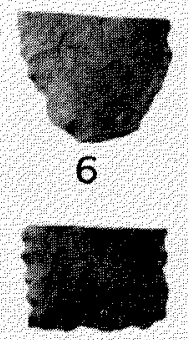

8

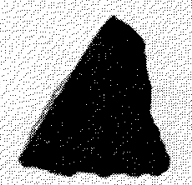

11

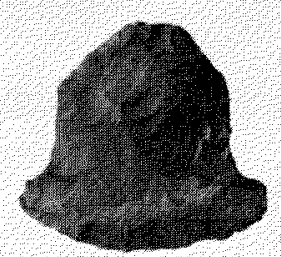

15

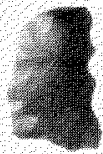

20
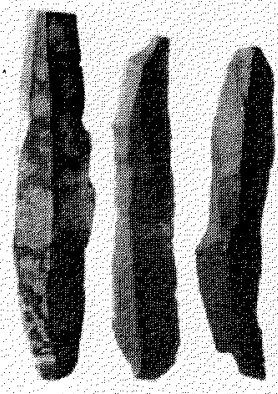
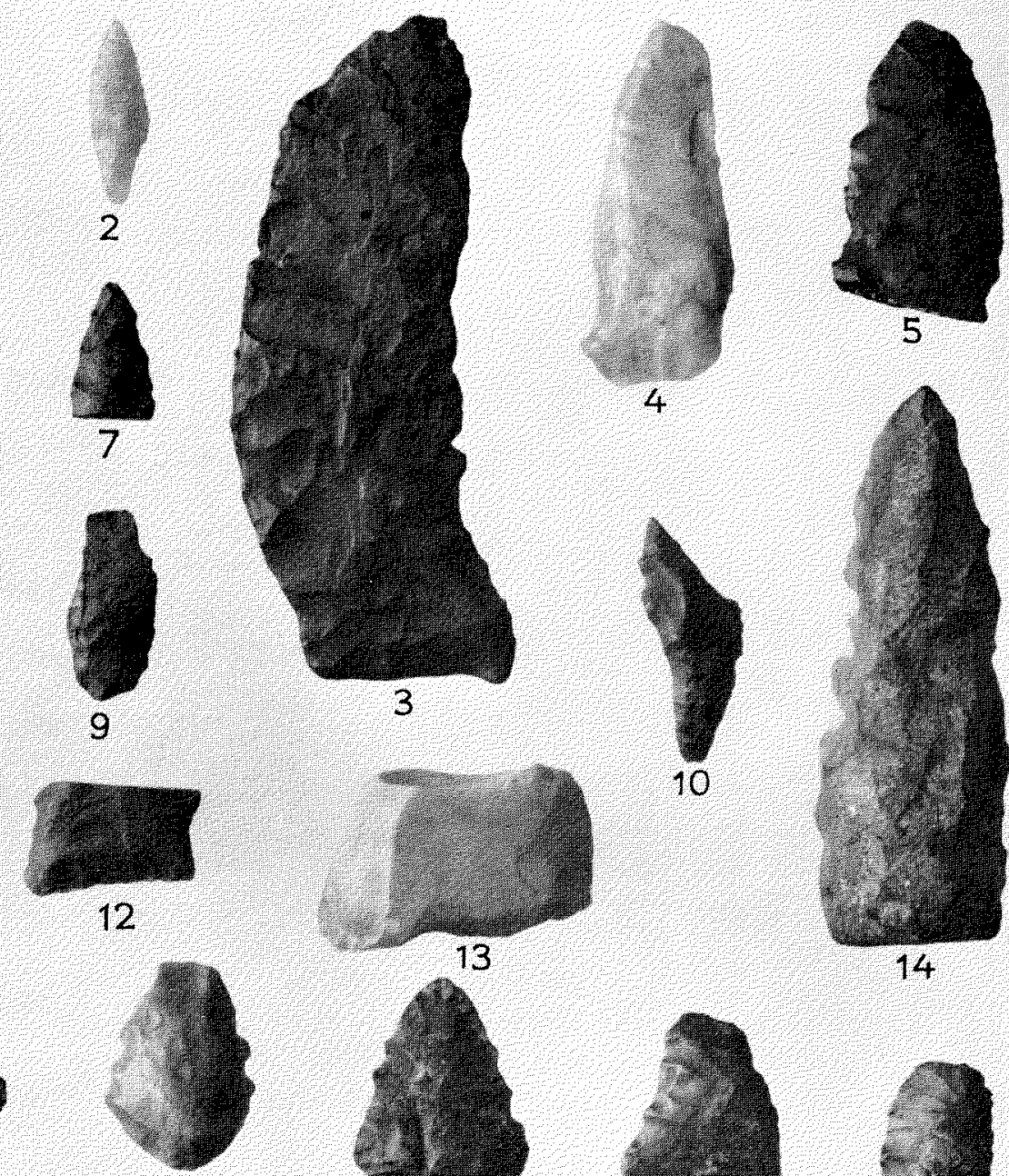

16

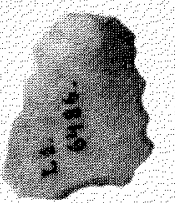

21
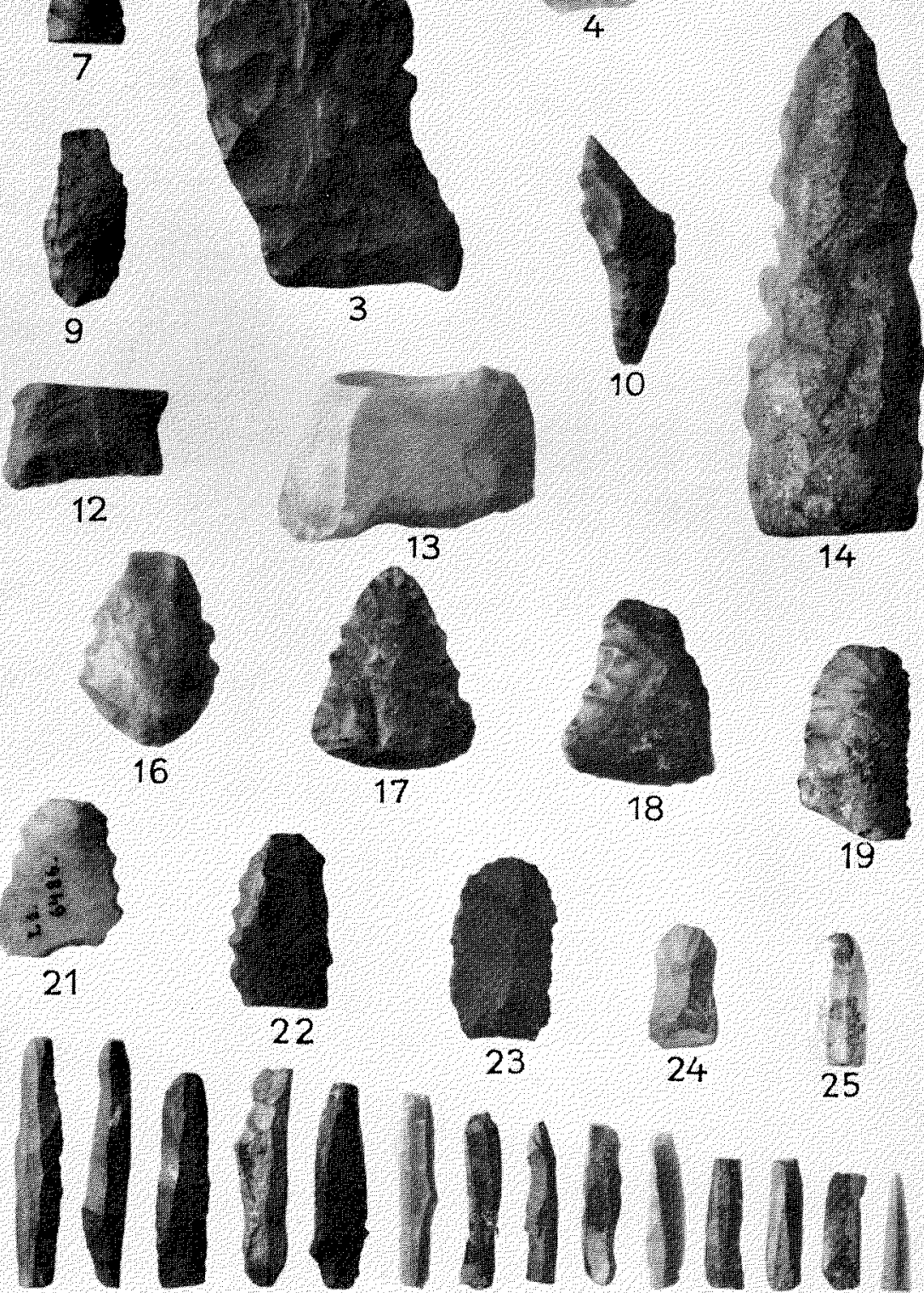

17.
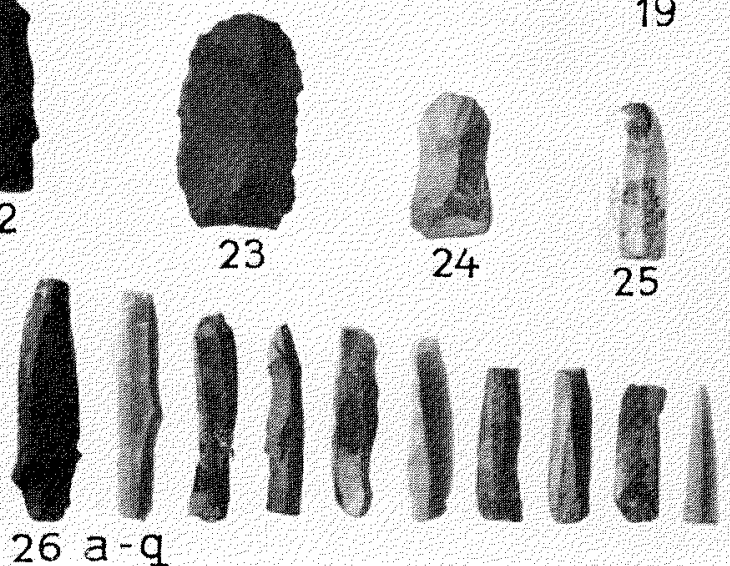

Fig. 10. Dorset flint artifacts from the Peary Land area: (1) projecting point; (2) arrow point; (3)-(5) knife blades; (6), (7) broken points; (8), (11), (12) back ends of knife blades; (9) burin; (10) concave-edged scraper blade; (13) prepared flint core; (14) adze blade; (15)-(18) convex-edged scraper blades; (19) flake scraper; (20)-(25) blades or parts of blades of uncertain use; $(26 \mathrm{a}-\mathrm{q})$ microliths. Reduction ca. 2:3. 
flint flaker, used for retouching (Fig. 11, Nos. 7-12) were found later, these were small forms used in handles, and are well known, for example, from Ipiutak.

The bone needles found (Fig. 11, Nos. 3-6) often had almost invisible eyes, some of which were oblong, some round. And eventually-after one whole year-a pair of much damaged harpoon heads emerged, a highly desirable find, because harpoon heads usually give a definite indication of the culture. One harpoon head (Fig. 11, No. 1) had a groove at one edge which must have been used for a side flint blade. This type had never been discovered in Greenland, and to find parallels we must once more turn to Eskimo cultures in Canada and Alaska. No less interesting was a burin (Fig. 10, No. 9), the splitting tool, well known from Stone Age Cultures (Upper Palaeolithic and Mesolithic) of Europe. That burins occur at all in Eskimo cultures is one of the most remarkable archaeological discoveries of recent years. They were first found by Giddings (1951) in 1948-9 in the oldest of three deposits at Norton Sound, Alaska, among the culture elements of what he calls the Denbigh Flint Complex. At the time of the Pearyland Expedition burins with microliths and flint cores were also excavated by Irving (1951) and by Lachenbruch and

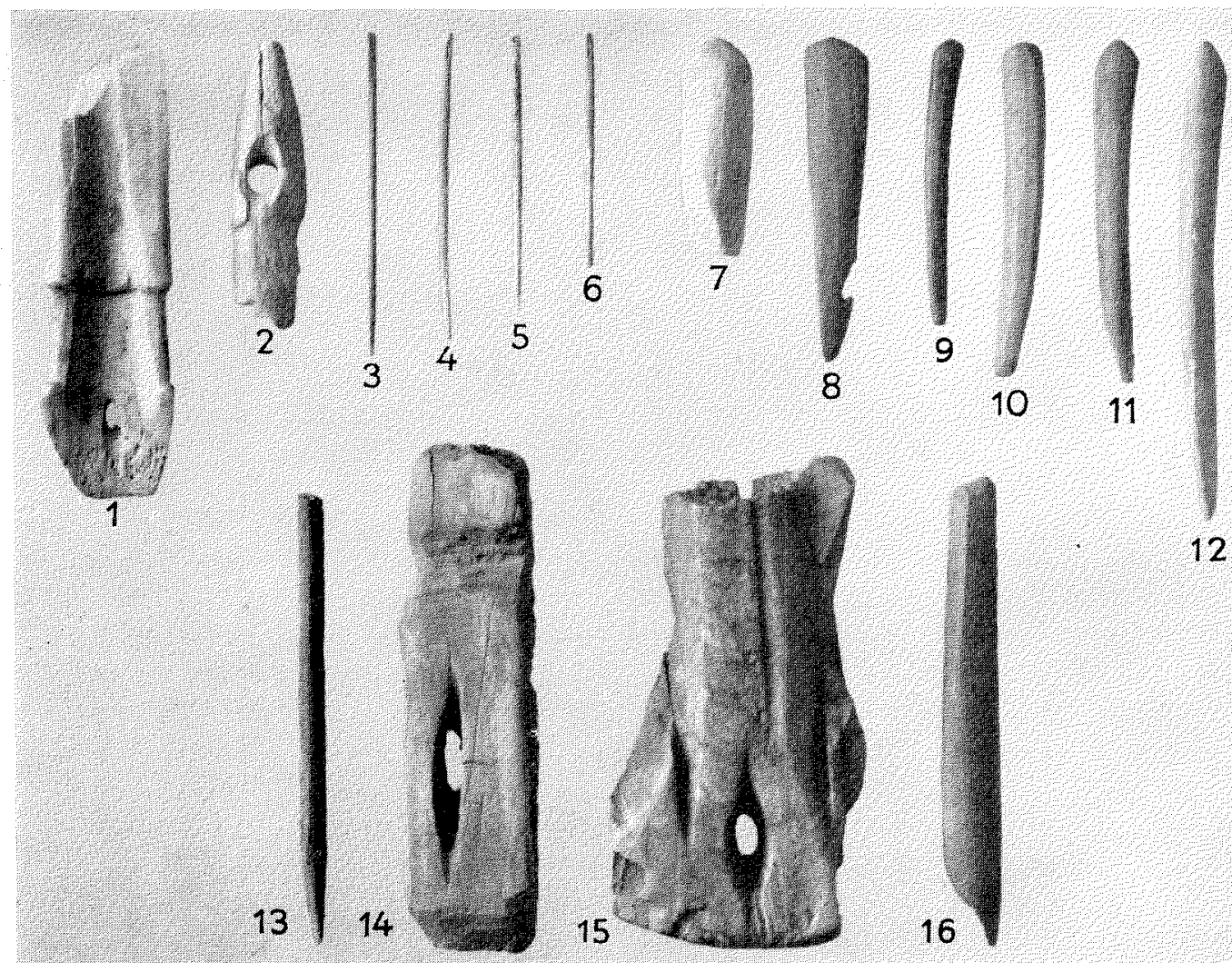

Fig. 11. Dorset bone objects from the Peary Land area: (1) harpoon head with groove for side blade; (2) harpoon head; (3)-(6) bone needles (4 and 6 with oblong eyes); (7)-(12) points for flint flakers; (13), (16) bone implements of uncertain use; (14), (15) preliminary works of ivory (15 presumably for a harpoon head). Reduction ca. 2:3. 
Hackman (Solecki, 1951; and Solecki and Hackman, 1951) in the Brooks Range. In the Denbigh Flint Complex the burins likewise occur in a microlithic layer with polyhedral cores, but more strikingly, they occur with blades of Folsom- and Yuma-type. This deposit was beneath a layer containing flints of Ipiutak and Dorset-like types, representing accordingly an earlier culture stage than these. Finally, Elmer Harp (1951) in 1949 collected flint implements from Dorset sites in southwestern Labrador, at the entrance to the Strait of Belle Isle, and his finds contain not only microliths and burins, but one flint point with basal flutes on both sides, a decidedly Folsom-like feature.

If the Peary Land flint and bone objects, like Harp's finds, are regarded as belonging to the Dorset Culture-and it is at present advisable to do sothey reveal a new side of the Dorset Culture, opening up perspectives on the

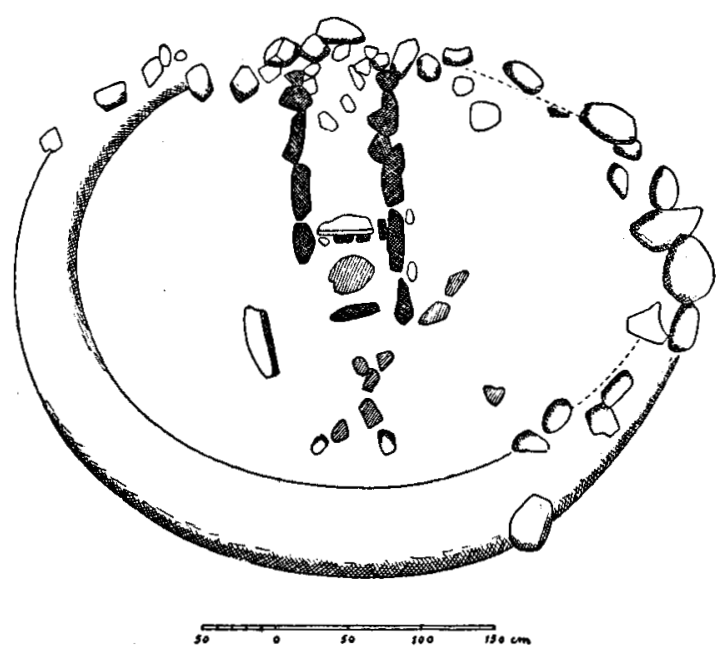

Fig. 12. Elliptical tent ring No. 11 with mid-passage at Deltaterrasserne, site $K$ in Jørgen Brønlunds Fjord.

Denbigh Flint Complex and by way of this on Stone Age Cultures of the Old World. The conception "Dorset Culture" is unfortunately not clearly defined as yet, one of the big unknowns of Eskimo archaeology, which more than ever needs a closer investigation. Lauge Koch (Mathiassen, 1928) and Erik Holtved (1944) have found Dorset remains in north Greenland in Hall Land and Inglefield Land, but compared with these the Peary Land implements are in several respects more primitive, such as in their total lack of ornamentation as well as in the simple forms of the harpoon heads. Other circumstances, too, give a hint of the age of the Dorset settlement in Peary Land. Age is indicated by the sterility typical of the gravel in the tent rings, where neither wood nor bones are found on the surface as they were in profusion at the umiak site. Again, the stones of the tent rings are all deeply polished on the same side by the strong winds, and this must therefore have taken place after the Eskimo had arranged the stones. At certain tent camps the stones must 
have been reduced to half their original volume. It is worth mentioning in this connection that the absence of bone material and the evidence of wind polishing were also observed by Harp in Labrador (1951).

The small number of bones found beneath the surface in the tent rings suggests that in accordance with paleo-Eskimo habits the Dorset people lived chiefly by hunting on land, probably on muskoxen and to a smaller extent on reindeer. They probably fished for trout off the river mouths and shot hares, ptarmigan, and brent geese, pursuing their game to the large Midsommer $S \varnothing$, the lake to the west of Jørgen Brønlunds Fjord, where tenting grounds were found. They do not seem to have built stone fox traps.

Since only a few objects were available for culture determination we had to make a close study of the forms of the despised tent rings (Fig. 9). The

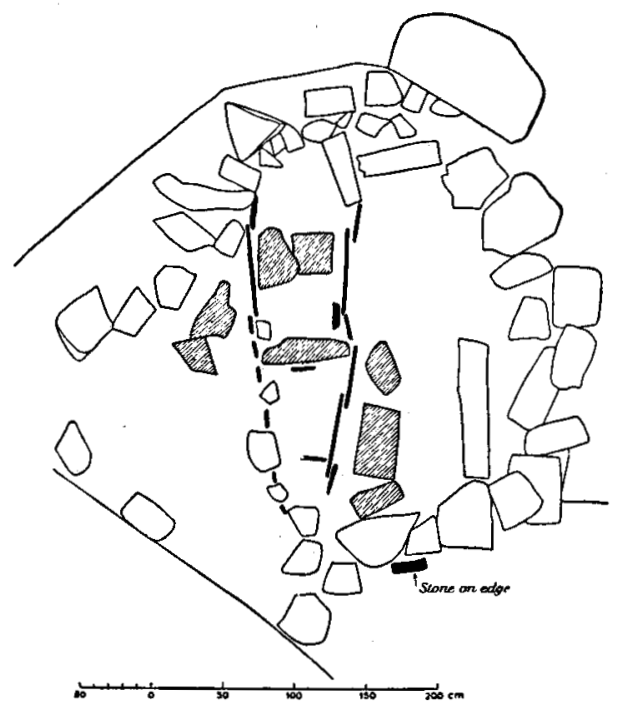

Fig. 13. Tent ring with mid-passage flanked by slender flags on edge at Røde $\emptyset$, Dove Bugt, northeast Greenland.

types of these varied in sites where the Dorset implements occurred, but they had certain features in common which are presumably Dorset characteristics: (1) the stones are placed closely together and partly buried in the ground, whereas the stones of the Thule tent rings, also found in Bronlunds Fjord, were scattered on top of the gravel; (2) there is an open fire place inside the tent; (3) slender, long flags are used, standing on edge half-way or completely buried so that only the upper edge is visible; (4) the rings are, as a rule, on sterile gravel terraces much higher up (sometimes 50-60 feet) and farther from the coast (in one case over 200 yards) than is usual for tenting grounds; and finally there is the elliptical type of tent ring, which should also be taken into consideration.

Elliptical tent rings were predominant in one particular locality, Deltaterrasserne, far up Brønlunds Fjord, but were also found elsewhere in Peary Land. These rings consisted of either a stone circle or an almost invisible gravel wall, 
with a paved passage flanked by flat stones or slender flags on edge leading from the front wall to the back. Two rows of stones across the central part of the passage marked a square, also paved, and a layer of charcoal and charred bones showed that here was the fire place (Fig. 12).

The absence of real winter houses and the solid construction of the Peary Land Dorset rings must mean that these constructions represent a more permanent dwelling than tent rings in general, and might be termed tent bouses. The Dorset people may have used these habitations, covered with hides, far into the autumn and possibly the whole year round. This coincides with results of Dorset excavations in east Canada, where indisputable winter houses were also absent. Wintemberg (1939) mentions "low circular piles of rough rocks" as "probably house ruins" on Keppel Island (p. 86), and at Cow Head only "many chipping places and also what were probably fire places" (p. 88). Leechman (1943, p. 366) describes his "houses" at Nuvuk Island as "very shallow circular depressions" in banks of coarse gravelly sand, with hardly any sign of walls. Rowley (1940, p. 496) says of his Foxe Basin site that "unlike the Thule Eskimo again, the Abverdjar natives did not live in stone houses, (though the many fox-bones show that the site was occupied in winter), but in houses, presumably of either turf or snow". And finally the "houses" on Harp's site Port au Choix-2 (Newfoundland) were "shallow round pits" with diameters ranging between 10 and 15 feet (Harp, 1950). They had a hearth in the entrance gap and were surrounded by a ridge under which digging revealed a ring of stones "piled around the exterior edges of a dwelling, possibly to anchor it to the ground." Harp makes the same conclusion as I do, writing that "it seemed, that the aborigines who once dwelt here probably lived in skin tents, all other traces of which had long since disappeared."

Many small features characteristic of the Peary Land tent foundations may be found in tent ruins elsewhere in the Eskimo world, principally in Greenland. The solidly-founded stone arrangements had already been pointed out in the Dove Bugt area, 400 miles south of Peary Land, by Bendix Thostrup in 1907 when taking part in the Danmark Expedition. Thostrup (1911) mentions the elliptical type with mid-passage, and states that it appeared to be much older than the other types nearby. I was able to confirm this statement after visits to the Dove Bugt area, most recently in the summer of 1950 on returning from Peary Land, and in 1939, I found a small adze blade of black flint corresponding to those of the Dorset Culture in such a mid-passage ring on Røde $\emptyset$ (Fig. 13).

In 1949 , when waiting at Zackenberg in Young Sund, $74^{\circ} 30 \mathrm{~N}$., the starting place for our Peary Land flights, I found a Dorset site on a high barren terrace. Flint burins also occurred here (Fig. 14, Nos. 4-7) among microliths and chipped flint pieces. A flint side blade (Fig. 14, No. 1), was the first to be found in East Greenland; an oblong flake end-scraper (Fig. 14, No. 21) and a rather thick tool with one corner pointed, probably for graving (Fig. 14, No. 23), must be considered as quite new types in Eskimo archaeology, though the flake end-scraper is known from the European Stone Age, and forms a new link between the cultures of the North American-Greenland Arctic and the 
One of them may, however, have passed into our hands-a small flint arrow point (Fig. 15) found on the beach in front of the ruin site of the large Sandnes farm at Kilarsarfik in Godthaab district during Nørlund's excavations in 1930 (Roussell, 1936, p. 106). It is not unlike points from Harp's finds.

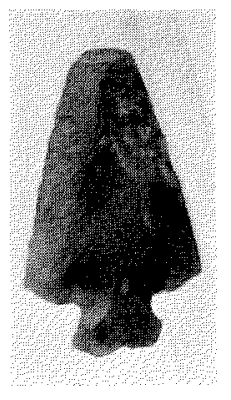

Fig. 15. Flint arrow point found at Sandnes Farm near Kilarsarfik, which belonged to Thorstein, son of Erik the Red, and after Thorstein's death passed to Thorfinn Karlsefne, who spent two winters in Vineland.

If we look back from Greenland to the Central Eskimo territories and examine Mathiassen's (1927) and more recent workers' notes on tenting grounds there, we again come across the remarkably solid and always highlying stone rings or stone walls. They are referred to the Thule Culture, but no one has dug them carefully because rich house ruins were close at hand, and finds have never been made in them. Consequently, no one can objectively challenge the assumption that at least some of them are from an old Dorset occupation, which covered large areas of the Eskimo region and was strong enough also to populate Greenland. A hypothesis on such an early Dorset-stage extending over a large territory has recently been put forward by Birket-Smith (1950).

The known Dorset localities today extend from Newfoundland in the south to the northernmost shores of Peary Land. It is to be hoped that more information will be forthcoming on this strange old Eskimo culture the problems of which are of immediate importance to archaeologists. It seems that more clarity on this point is needed for further investigations on the wide subject of the origin of the whole Eskimo culture.

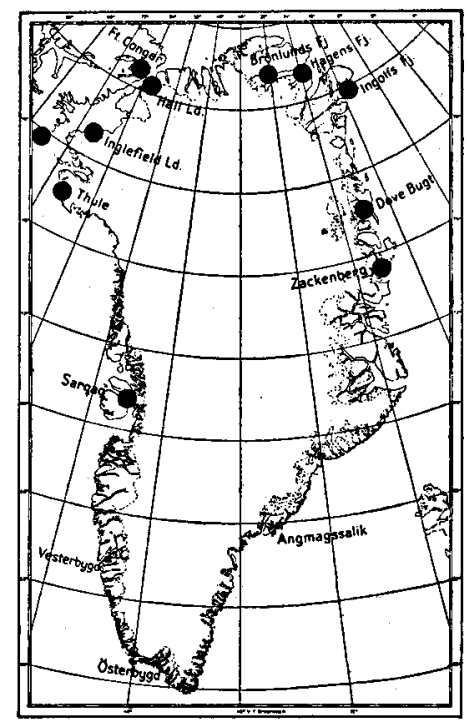

Fig. 16. Dorset finds in Greenland.

\section{References}

Bentham, Robert and Diamond Jenness. 1941. "Eskimo remains in S.E. Ellesmere Island". Trans. Roy. Soc. Can. Vol. 35, Section II, pp. 41-56.

Birket-Smith, Kaj. 1950. "Nye fremskridt inden for Eskimoforskningen". Fra Nationalmuseets Arbejdsmark, København, pp. 81-100. 
Collins, Henry B. 1937. 'Archaeology of St. Lawrence Island, Alaska'. Smitbsonian Misc. Collections, Vol. 96, $431 \mathrm{pp}$.

1943. "Eskimo archaeology and its bearing on the problem of man's antiquity in America". Proc. Amer. Pbil Soc. Vol. 86 (1942-3) pp. 220-35.

Frode, Are hinn, Thorgilsson. 1930. 'Islendingabok'. Edited by Finnur Jonsson. København. Vol. VII, Pt. 20, 72 pp.

Geist, O. W. and Froelich Rainey. 1936. 'Archaeological excavations at Kukulik, St. Lawrence Island, Alaska'. Misc. Publ. Univ. of Alaska, Vol. 2, $391 \mathrm{pp.}$

Giddings, J. L. 1949. "Early flint horizons on the north Bering Sea Coast". J. Wash. Acad. Sci. Vol. 39, pp. $8 \dot{5}-90$.

1951. "The Denbigh Flint Complex". Amer. Antiquity, Vol. 16 (1950-1) pp. 193-203.

Greely, A. W. 1888. 'Report on the proceedings of the United States Expedition to Lady Franklin Bay, Grinnell Land'. Washington, Vol. 1, 545 pp.

Harp, Elmer. 1950. "A detective story from the far north". Dartmouth Alumni Magazine, Nov., 3 pp.

1951. "An archaeological survey in the Strait of Belle Isle area". Amer. Antiquity, Vol. 16 (1950-1) pp. 203-20.

Holtved, Erik. 1944. 'Archaeological investigations in the Thule district'. Medd. om Grøn. Vol. 141, Nos. 1 and 2, $308 \mathrm{pp}$. and $184 \mathrm{pp}$.

Irving, William. 1951. "Archaelogy in the Brooks Range of Alaska". Amer. Antiquity, Vol. 17 (1951-2) p. 52.

Jenness, Diamond. 1925. "A new Eskimo culture in Hudson Bay". Geogr. Rev. Vol. 15, pp. $428-37$.

Larsen, Helge. 1934. 'Dødemandsbugten. An Eskimo settlement on Clavering Island'. Medd. om Grøn. Vol. 102, $186 \mathrm{pp}$.

Larsen, Helge and Froelich Rainey. 1948. 'Ipiutak and the Arctic Whale Hunting Culture'. Antbro. Pap. Amer. Mus. Nat. Hist. Vol. 42, 276 pp.

Leechman, Douglas. 1943. "Two new Cape Dorset sites". Amer. Antiquity, Vol. 8 (1942-3) pp. 363-75.

Lethbridge, T. C. 1939. "Archaeological data from the Canadian Arctic". J. Roy. Anthro. Inst. Vol. 69, Pt. 2, pp. 187-233.

Mathiassen, Therkel. 1927. 'Archæology of the Central Eskimos'. Rep. Fifth Thule Exped. 1921-24. Copenhagen, Vol. 4, Pts. 1 and 2, 327 pp. and $208 \mathrm{pp}$.

1928. 'Eskimo relics from Washington Land and Hall Land'. Medd. om Grøn. Vol. 71, pp. 183-216.

Meldgaard, Jørgen. 1952. "A paleo-Eskimo culture in west Greenland". Amer. Antiquity, Vol. 17 (1951-2) pp. 222-30.

Roussell, Aage. 1936. 'Sandnes and the neighbouring farms'. Medd. om Gron. Vol. 88, $219 \mathrm{pp}$.

Rowley, Graham. 1940. "The Dorset Culture of the Eastern Arctic". Amer. Antbropologist, New Ser., Vol. 42, pp. 490-9.

Solberg, O. 1907. 'Beiträge zur Vorgeschichte der Osteskimo'. Christiania, 92 pp.

Solecki, Ralph S. 1950. "A preliminary report of an archaeological reconnaissance of the Kukpowruk and Kokolik rivers in northwestern Alaska". Amer. Antiquity, Vol. 16 (1950-1) pp. 66-9.

1951. "Additional data on the Denbigh Flint Complex in northern Alaska". J. Wash. Acad. Sci. Vol. 41, pp. 85-8.

Solecki, Ralph S. and Robert J. Hackman. 1951. "Notes on two archaeological discoveries in northern Alaska, 1950". Amer. Antiquity, Vol. 17 (1951-2) pp. 55-7.

Thostrup, Christian Bendix. 1911. 'Ethnographic description of the Eskimo settlements and stone remains in north-east Greenland'. Medd. om Gron. Vol. 44, pp. 179-355.

Wintemberg, W. J. 1939 and 1940. "Eskimo sites of the Dorset Culture in Newfoundland". Amer. Antiquity, Vol. 5 (1939-40) pp. 83-102 and 309-33. 